\title{
Risk Assessment of Polycyclic Aromatic Hydrocarbons Concentration in Cold Smoked Mullet Fish (Mugil cephalus)
}

\author{
Nabil El-Sayed Hafiz ${ }^{1}$, Awad Abd-El-Tawab Mahmoud ${ }^{1}$, Sayed Mekawy Ibrahim², \\ Hassan Rabea Mohamed ${ }^{2, *}$, Adel Ammar El-Lahamy ${ }^{2}$ \\ ${ }^{1}$ Department of Food Science and Technology, Faculty of Agriculture, Fayoum University, Faiyum, Egypt \\ ${ }^{2}$ Fish Processing and Technology Laboratory, Fisheries Division, National Institute of Oceanography and Fisheries, Cairo, Egypt
}

Email address:

nsh03@fayoum.edu.eg (N. El-Sayed H), aam09@fayoum.edu.eg (A. Abd-El-Tawab M), Ibrahim_niof@yahoo.com (S. M. Ibrahim), Hassanaboali66@yahoo.com (H. R. Mohamed)

${ }^{*}$ Corresponding author

\section{To cite this article:}

Nabil El-Sayed Hafiz, Awad Abd-El-Tawab Mahmoud, Sayed Mekawy Ibrahim, Hassan Rabea Mohamed. Risk Assessment of Polycyclic Aromatic Hydrocarbons Concentration in Cold Smoked Mullet Fish (Mugil cephalus). World Journal of Food Science and Technology. Vol. 3, No. 1, 2019, pp. 1-5. doi: 10.11648/j.wjfst.20190301.11

Received: January 19, 2019; Accepted: February 27, 2019; Published: April 22, 2019

\begin{abstract}
The purpose of this work was to determine the concentration and risk assessment of Polycyclic Aromatic Hydrocarbons (PAHs) in cold-smoked mullet fish samples which were pre-frozen at $-18^{\circ} \mathrm{C}$ for 6 months. Fish samples were obtained from two fish farms; A (Al-Batts drain) and B (El-Wadi drain), El-Fayoum governorate, Egypt. 16 components of PAHs concentration were determined by GC-MS. Results showed that the total concentration of PAHs recorded16.2 and 7.4 ppb sample of A- and B-smoked mullet fish products, respectively. Also, levels of Benzo [a] Pyrene (B \{a\} P) equivalent were 0.0378 and $0.029 \mathrm{ppb}$ in A and B-products, respectively. Besides, content of Low molecular weight (LMW) components was higher in A-smoked mullet product than medium MW and vice versa in case B-smoked product however, high MW was not detected in products. In conclusion, PAHs concentration in smoked products processed from pre-frozen mullet samples for 6 months at $-18^{\circ} \mathrm{C}$ are considered a minimally contaminated (16.2 ppb) for A-smoked product and not contaminated (7.4 ppb) for B-smoked product compared with recommended levels. In addition to the component of Benzo [a] Pyrene (B \{a\} P) was not detectable in all smoked fish products.
\end{abstract}

Keywords: PAHs, Frozen Mullet Fish, Smoking, GC-MS

\section{Introduction}

Smoking is one of the oldest methods used to process and preserve fish. It is a process of treating fish by exposing it to smoke from smoldering wood or plant materials. This process is usually characterized by an integrated combination of salting, drying, heating and smoking operations in a smoking chamber. The preservation properties of smoking treatment are mainly due to the partial drying and the precipitation of aliphatic and aromatic vapors on fish surface [1-6]. Food cooking and processing methods at high temperatures such as smoking, drying, roasting, baking or frying are recognized as a major source of food contamination by PAHs [7-10].

PAHs compounds are containing 2 or more fused aromatic rings. Polycyclic aromatic hydrocarbons containing 4 rings such as chrysene and benzo [a] anthracene consider weakly carcinogenic compounds, while PAHs which have 5 or more rings are a potentially carcinogenic and mutagenic for human such as benzo [a] pyrene ( $\mathrm{BaP})$, benzo [g, h, i] perylene, benzo $[\mathrm{b}]$ fluoranthene, indeno $[1,2,3-\mathrm{c}, \mathrm{d}]$ pyrene and benzo [k] fluoranthene [11-13].

Wood smoke contains a hundreds (a least 100) of PAHs and their derivatives which have carcinogenic compounds such as Benzo [a] pyrene (BaP). $\mathrm{BaP}$ consider a marker for carcinogenic PAHs in smoked fish and the maximum level is $2 \mu \mathrm{g} / \mathrm{kg}$. After metabolic activation in mammalian cells to diol-epoxides, PAHs bind covalently to cellular macromolecules, including DNA, thereby causing errors in DNA replication and mutations that initiate the carcinogenic 
process. This mechanism of activation, with some modifications, occurs with all carcinogenic PAHs [14]. The classification of the International Agency of Research on Cancer for benzo [a] pyrene ( $\mathrm{BaP})$ was changed from group 2A (probably carcinogenic to humans) to group 1 (carcinogenic to humans), chrysene was changed from group 3 (not classifiable for humans) to group 2B (possibly carcinogenic to humans), and benzo [a] anthracene was regrouped from $2 \mathrm{~A}$ to $2 \mathrm{~B}$ [15-16].

Therefore, the main purpose of this work was to determine the concentration and risk assessment of Polycyclic Aromatic Hydrocarbons (PAHs) in cold-smoked mullet fish samples which were obtained from two fish farms, El-Fayoum governorate, Egypt and frozen storage at $-18^{\circ} \mathrm{C}$ for 6 months.

\section{Materials and Methods}

\subsection{Fish Samples}

Mullet fish (Mugil cephalus) samples were obtained after directly catch from two fish farms (A and B). The main resources of irrigation water were agricultural discharge for $\mathrm{A}$ (Al-Batts drain) and B (El Wadi drain) during August, 2015 at El-Fayoum governorate, Egypt. They were transported immediately to Fish Processing and Technology Lab, Shakshouk Station for Water Resource, National Institute of Oceanography and Fisheries (NIOF), Egypt. Average of weight $525 \pm 25 \mathrm{gm}$ and length $36 \pm 1 \mathrm{~cm}$ for raw samples from Farm A (Al-Batts drain) while, the average weight of raw mullet samples from Farm B (Agricultural discharge) was $545 \pm 5 \mathrm{gm}$ and length was $37.75 \pm 0.25 \mathrm{~cm}$, respectively. After that, fish samples were carefully washed with tap water, glazed, packed in polyethylene bags and stored at $-18^{\circ} \mathrm{C}$ for 6 months.

\subsection{Smoking Process}

After 6 months of raw mullet fish frozen storage, Fish samples (from A and B farm) were thawed at $4{ }^{\circ} \mathrm{C}$ then soaked in $10 \%$ brined solution (Sodium chloride) for two hrs., rinsed with tap water for $1 \mathrm{~min}$ and semi-dried at $25^{\circ} \mathrm{C}$ for two hrs. The smokehouse had inside dimensions of $1.20 \times 1.0 \times 3.5 \mathrm{~m}$ with pours-metal plates localized above the smoke source by $75 \mathrm{~cm}$. the Semi-dried fish samples were hooked at distance about $250 \mathrm{~cm}$ in smoking house. Traditional cold smoking was carried out at $28-32^{\circ} \mathrm{C}$ for $8-10$ hrs. using sawdust as smoke source. After smoking the fish samples were cooled under ambient temperature.

\subsection{Analytical Methods}

The edible of smoked mullet fish products was manually separated, homogenized, packed in polyethylene bags and then stored in a freezer at $-20^{\circ} \mathrm{C}$ till analysis. PAHs were determined at Central Laboratory of Residue Analysis of Pesticides and Heavy Metals in Food (QCAP), Agricultural Research Centre. Cairo, Egypt as described by [17]. Chemicals and Reagents; acetone (Riedel-de Häen, purity 99.8\%), acetonitrile (Sigma-Aldrich, purity $>99.9 \%$ ), toluene
(Merck), dichlorom-ethane chromatography grade, and nhexane (purity $>99.0 \%$ ) were used.

$\mathrm{B}\{\mathrm{a}\} \mathrm{P}$ equivalent

The $\mathrm{BaP}_{\text {eqi }}$ was calculated as the sum of $\mathrm{BaP}_{\text {eqi }}$ value for individual PAHs. The $\mathrm{BaP}_{\text {eqi }}$ value was calculated for each $\mathrm{PAH}$ from its concentration in the sample $\left(\mathrm{C}_{\mathrm{PAHi}}\right)$ multiplied by its toxic equivalency factor $\left(\mathrm{TEF}_{\mathrm{PAHi}}\right)$ [18].

$$
\text { BaPeq }=\Sigma\left(\text { BaP }_{\text {eqi }}\right)=\Sigma\left(\mathrm{C}_{\text {PAHi }} \times \mathrm{TEF}_{\text {PAHi }}\right)
$$

\section{CPAHi}

Concentration of each PAH in the sample; TEFPAHi: Toxic equivalency factor for each individual PAH.

\subsection{Statistical Analysis}

The results obtained were analyzed statistically using the least significant difference test $(\mathrm{LSD})$ at $(\mathrm{P} \leq 0.05)$ and were expressed as Mean \pm SD using SPSS 16 for windows.

\section{Results and Discussion}

\subsection{Polycyclic Aromatic Hydrocarbons (PAHs)}

Table 1 shows the PAHs concentration of cold smoked mullet fish flesh. 16 components of PAHs were detected in edible part of investigated smoked products including ; naphthalene (NA), acenaphthylene (ACL), acenaphthene (ACE), fluorine (FLU), phenanthrene (PHE), anthracene (ANT), fluoranthene (FLA), pyrene (PYR), benzo [a] anthracene (BaA), chrysene (CHR), benzo [b] fluoranthene $(\mathrm{BbF})$, bonzo [k] fluoranthene $(\mathrm{BkF})$, benzo [a] pyrene $(\mathrm{BaP})$, dibenzo $[\mathrm{a}, \mathrm{h}]$ anthracene (DahA), benzo $[\mathrm{g}, \mathrm{h}, \mathrm{i}]$ pyrene (BghiP) and indeno [1, 2, 3-cd] pyrene (IcdP). The results showed that A-smoked samples contained 5 compounds; Phenanthrene (4.9 ppb), Fluorene (3.8 $\mu \mathrm{g} / \mathrm{kg})$, Fluoranthene (2.6 ppb), Pyrene (2.5 ppb) and Anthracene (2.5 ppb). $\Sigma 16$ PAHs was $16.2 \mathrm{ppb}$. While B-smoked samples contained 5 compounds; Fluoranthene (2.6 ppb), Pyrene, Anthracene (2.4 ppb), Fluorene and Phenanthrene (<LOQ) and they were lower than the limit of quantification of PAHs $(<$ LOQ) $(<2 \mathrm{ppb})$ and $\Sigma 16$ PAHs were $7.4 \mathrm{ppb}$.

\subsection{Toxic Equivalent Factors (TEFs) and $B\{a\} P$ Equivalent of PAHs Found in Smoked Mullet Fish Samples}

Toxic equivalency factor (TEF) is an estimate of the relative toxicity of individual $\mathrm{PAH}$ fraction compared to benzo (a) pyrene. TEFs have been applied as a useful tool for the regulation of compounds with a common mechanism of actions (e.g PAHs) [19]. Even if this presentation of PAH content is empirical because the effects of PAHs in a mixture are insufficiently understood, with this approach it is possible to express PAH contamination of food by a single value as reported [20-21]. Benzo [a] Pyrene (BaP) has been well characterized as the most potent carcinogenic PAH after dibenz $[\mathrm{a}, \mathrm{h}]$ anthracene. Therefore, the total PAH concentration is expressed as Benzo [a] Pyrene Equivalents 
$\left(\mathrm{BaP}_{\mathrm{eq}}\right)$ to illustrate the toxic potency [22].

The toxic equivalent factors (TEFs) and B [a] P Equivalent of PAHs in smoked mullet fish are presented in Table 2. The $\mathrm{B}$ [a] P Equivalent of Fluorene; Phenanthrene; Anthracene; Fluoranthene and Pyrene were 0.0038; 0.0049; 0.024; 0.0026 and 0.0025 respectively and the $\sum\left(\mathrm{BaP}_{\text {eqi }}\right)$ was 0.0378 for farm A smoked samples. In the other farm samples (B) the B [a] P Equivalent of Anthracene; Fluoranthene and Pyrene were $0.024 ; 0.0026$ and 0.0024 respectively and the sum of $B$ [a] P Equivalent $\left(\sum\left(\mathrm{BaP}_{\text {eqi }}\right)\right.$ were 0.029.

Table 1. Concentration of polycyclic aromatic hydrocarbons (PAHs) in cold-smoked mullet fish samples pre-frozen for 6 months at - $18^{\circ} \mathrm{C}$.

\begin{tabular}{|c|c|c|c|c|c|}
\hline \multirow{2}{*}{ Compound } & \multirow{2}{*}{ Abbrev. } & \multirow{2}{*}{ Mw } & \multirow{2}{*}{ Rings } & \multicolumn{2}{|c|}{ Concentration ( ppb ) } \\
\hline & & & & Farm (A) & Farm (B) \\
\hline Chrysene & $\mathrm{CHR}$ & 228 & 4 & ND & ND \\
\hline Anthracene & ANT & 178 & 3 & 2.4 & 2.4 \\
\hline Acenaphthene & $\mathrm{ACE}$ & 153 & 3 & ND & ND \\
\hline Benzo (b) Fluoranthene & $\mathrm{BbF}$ & 252 & 5 & ND & ND \\
\hline Benzo (k) fluoranthene & $\mathrm{BkF}$ & 252 & 5 & ND & ND \\
\hline Dibenzo $(a, h)$ Anthracene & DahA & 278 & 5 & ND & ND \\
\hline Naphthalene & NA & 128 & 2 & ND & ND \\
\hline Benzo (a) pyrene & $\mathrm{BaP}$ & 252 & 5 & ND & ND \\
\hline Benzo $(g, h, i)$ perylene & BghiP & 276 & 6 & ND & ND \\
\hline Indeno $(1,2,3-c, d)$ pyrene & IcdP & 276 & 6 & ND & ND \\
\hline Acenaphthylene & $\mathrm{ACY}$ & 152 & 3 & ND & ND \\
\hline Fluoranthene & FLA & 202 & 4 & 2.6 & 2.6 \\
\hline Pyrene & PYR & 202 & 4 & 2.5 & 2.4 \\
\hline Phenanthrene & PHE & 178 & 3 & 4.9 & $<$ LOQ \\
\hline$\Sigma 16 \mathrm{PAHs}$ & & & & 16.2 & 7.4 \\
\hline
\end{tabular}

Farm (A): Al-Batts Drain. Farm (B): El-Wadi Drain. Mw: Molecular weight. LOQ: < $2 \mu \mathrm{g} / \mathrm{kg}$. ND: not detected

Table 2. Toxic Equivalent factors (TEFs) and B [a] P Equivalent of PAHs found in pre-frozen cold smoked mullet fish for 6 months at -18 ${ }^{\circ}$ C.

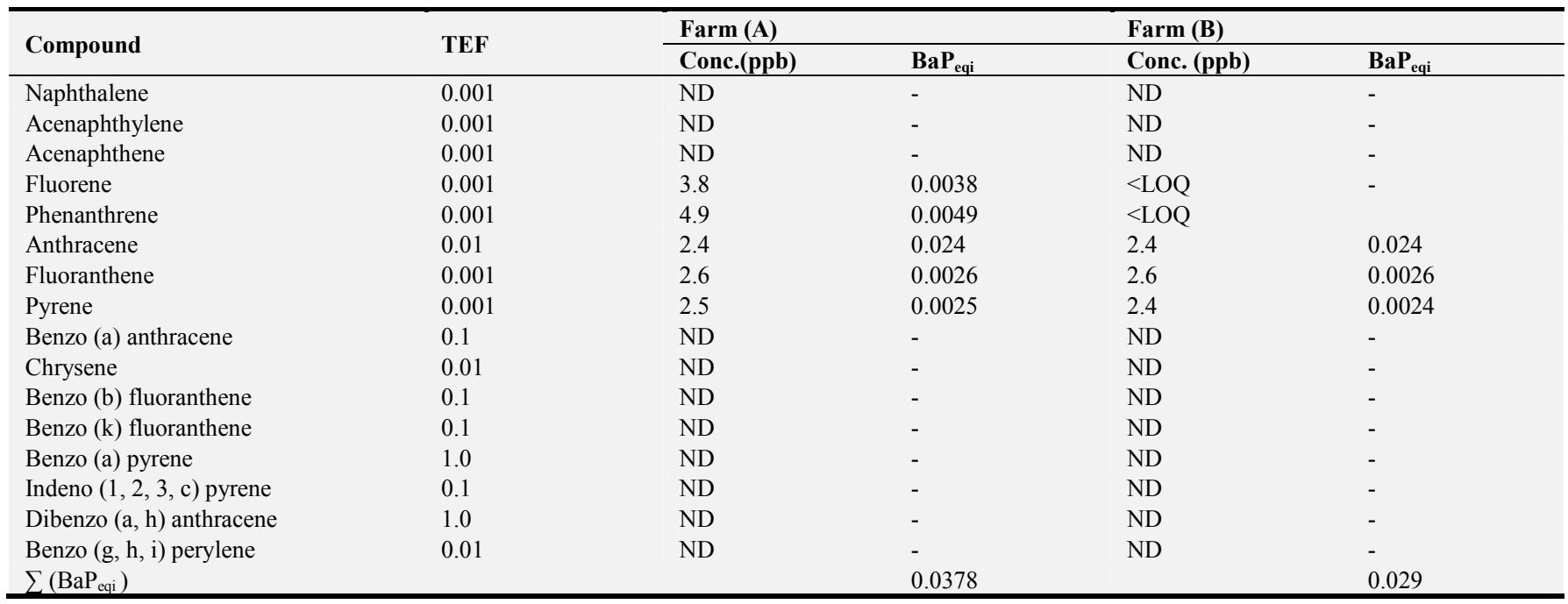

TEF: Toxic equivalent factor. $\mathrm{BaP}_{\text {eqi }}$ [a]: P equivalent. Farm (A): Al-Batts Drain. Farm (B): El-Wadi Drain

\subsection{Molecular Weight of PAHs in Smoked Fish}

Table 3 illustrates the molecular weights (MW) of PAHs in smoked mullet fish. The total concentration of the low molecular weights (LWM) of PAHs was higher than the medium molecular weights (MMW) in smoked fish farm (A). The concentration of LWM in smoked fish farm (A) was 11.1 ppb while MMW was $5.1 \mathrm{ppb}$. On the other side, for samples from $\mathrm{B}$ farm the total concentration of medium molecular weights of PAHs $5 \mu \mathrm{g} / \mathrm{kg}$, and LMW was $2.4 \mu \mathrm{g} / \mathrm{kg}$. The high molecular weight compounds not detected in samples from both farms A and B, Most of the carcinogenic PAHs fall within the group of the HMW [23]. This can be suggested to have been influenced by low fat and pyrolysis resulted from melted dropping onto the heat source. This is due to the average temperature of the smoking processes does not favor the production of $\mathrm{HMW}$ PAHs. The temperature range of $500-900^{\circ} \mathrm{C}$ is known to favor the production of HMW PAHs from thermal breakdown of lignin in lignocelluloses during wood combustion and also from pyrolysis of fats in fish [24$28]$. 
Table 3. Total mean concentration (ppb) of PAHs in cold smoked fish, according to their molecular weights.

\begin{tabular}{lllll}
\hline Concentrations (ppb) of the PAHs for Farm A samples & \multicolumn{3}{c}{ Concentrations (ppb) of the PAHs for Farm B samples } \\
\hline HMW & MMW & LMW & HMW & MMW \\
\hline- & 5.1 & 11.1 & - & 5 \\
\hline
\end{tabular}

HMW: high molecular weight. MMW: medium molecular weight. LMW: low molecular weight

Farm (A): Al-Batts Drain. Farm (B): El-Wadi Drain. - : was not detectable.

\subsection{Category of PAH Concentration}

The categories of PAHs concentration as not contaminated ( $<10 \mathrm{ppb})$; minimally contaminated (10-99 ppb); moderately contaminated (100-1000 ppb) and highly contaminated ( $>$ $1000 \mathrm{ppb})$ [29].

Category of PAH concentration (ppb) in the studied smoked samples is shown in Table 4. Concentrations of
PAHs were 16.2 and $7.4 \mathrm{ppb}$ in smoked fish from farms (A) and $(\mathrm{B})$, respectively. Based on these results, categories of concentration of PAH are considered a minimally contaminated (10-99 ppb) for A-smoked product, may be due to pollutants presented in Al-Bats drain and not contaminated $(<10 \mathrm{ppb})$ for B-smoked product compared with recommended levels as set by [29].

Table 4. Category of PAH concentration (ppb) in the studied cold smoked mullet samples.

\begin{tabular}{|c|c|c|c|}
\hline A-smoked mullet product & & B-smoked mullet & \\
\hline Category & इPAHs (ppb) & Category & इPAHs (ppb) \\
\hline Minimally contaminated & 16.2 & Not contaminated & 7.4 \\
\hline
\end{tabular}

Farm (A): Al-Batts Drain. Farm (B): El-Wadi Drain.

\section{Conclusion}

It could be concluded PAHs concentration in smoked mullet products processed from pre-frozen mullet samples for 6 months at $-18^{\circ} \mathrm{C}$ are considered a minimally contaminated (16.2 ppb) for A-smoked mullet product and not contaminated $(7.4 \mathrm{ppb})$ for B-smoked product compared with recommended levels. In addition to the component of Benzo [a] Pyrene (B \{a $\}$ P) was not detectable in all smoked fish products.

\section{References}

[1] Swastawati, F., Suzuki, T., Dewi, E. N., and Winarni, T. (2000). The effect of liquid smoke on the quality and omega-3 fatty acids content of tuna fish (Euthynnus affinis). $J$. of Coastal Development, 3, 573-579.

[2] Simko, P. (2002). Determination of polycyclic aromatic hydrocarbons in smoked meat products and smoke flavouring food additives, J. Chromatogr. B 770 (1-2) 3-18.

[3] Hultmanna, L., Bencze Røra, A. M., Steinslandc, I., Rustad, T. and Ska ${ }^{\circ}$ ra, T. (2004). Proteolytic activity and properties of proteins in smoked salmon. Food Chemistry, 85, 377-378.

[4] Stołyhwo, A., and Sikorski, Z. E. (2005). Polycyclic aromatic hydrocarbons in smoked fish - A critical review. Food Chemistry, 91(2), 303-311.

[5] ilgin, S., Unlusayin, M., Izci, L, and Gunlu, A. (2008). The determination of the shelf life and some nutritional components of gilthead seabream (Sparus aurata L., 1758) after cold and hot smoking. Turkish J. of Veterinary and Animal Sciences, 32, 49-56.

[6] Shalaby, A. R. (2000). Relation between mackerel fish smoking and its chemical changes with emphasis on biogenic amines. J. Agric. Sci. Mansoura Univ., 25 (1): 353-365.
[7] (CCFAC), (2005). Codex Committee on Food Additives and Contaminants. Discussion paper on polycyclic aromatic hydrocarbons contamination. 37th Session, The Hague, the Netherlands.

[8] Moret, S, Purcaro, G. and Conte, L. S. (2005). Polycyclic aromatic hydrocarbons in smoked fish by gas chromatography mass spectrometry with positive-ion chemical ionization. J. Food Comp Anal 18: 857-869.

[9] Scientific Committee on Foods of EC, SCF, (2002). Opinion of the Scientific Committee on Food in the Risk to Human Health of PAHs in Food. Scientific Committee on Foods of EC, SCF, Brussels.

[10] Yurchenko, S. and Mölder, U. (2005). The determination of polycyclic aromatic hydrocarbons in smoked fish by gas chromatography mass spectrometry with positive-ion chemical ionization. J. of Food Composition and Analysis, 18(8), 857-CCFAC, (2005). Codex Committee on Food Additives and Contaminants. Discussion paper on polycyclic aromatic hydrocarbons contamination. 37th Session, The Hague, the Netherlands.869.

[11] Martorell I, Perelló G, Martí-Cid R, Castell V, Llobet JM, Domingo JL. (2010). Polycyclic aromatic hydrocarbons $(\mathrm{PAH})$ in foods and estimated PAH intake by the population of Catalonia, Spain. Temporal Trend. Environ. Int. 36: 424432.

[12] Zhang H, Xue M, Dai Z (2010). Determination of polycyclic aromatic hydrocarbons in aquatic products by HPLCfluorescence. J. Food Compos. Anal. 23: 469-474.

[13] Alomirah H, Al-Zenki S, Al-Hooti S, Zaghloul S, Sawaya W, Ahmed N, Kannan K (2011). Concentrations and dietary exposure to polycyclic aromatic hydrocarbons (PAHs) from grilled and smoked foods. Food Control 22: 2028-2035.

[14] Falcó G, Domingo JL, Llobet JM, Teixidó A, Casas C, Müller L (2003). Polycyclic aromatic hydrocarbons in foods: Human exposure through the diet in catalonia, spain. J. Food Protect. 66: 2325-2331. 
[15] IARC (1987). IARC Monographs on the Evaluation of Carcinogenic Risks to Humans. Overall Evaluations of Carcinogenicity. IARC Monographs. International Agency for Research on Cancer, Lyon, France.

[16] IARC. (2010). IARC Monographs on the Evaluation of Carcinogenic Risks to Humans. Some Non-heterocyclic Polycyclic Aromatic Hydrocarbons and Some Related Exposures. International Agency for Research on Cancer, Lyon, France (2010).

[17] Khorshid, M., Souaya, E. R., Hamzawy, A. H. and Mohammed, M. N. (2015). QuEChERS Method Followed by Solid Phase Extraction Method for Gas Chromatographic MassSpectrometric Determination of Polycyclic Aromatic Hydrocarbons in Fish. Int. J. of Analytical Chem. Article ID 352610 .

[18] Nisbet, I. C. T. and LaGoy, P. K., (1992). Toxic equivalency factors (TEFs) for polycyclic aromatic hydrocarbons (PAHs)," Regulatory Toxicology and Pharmacology, vol. 16, pp. 290300 .

[19] Isioma T., Ozekeke O. and Lawrence E. (2017). Human health risk assessment of polycyclic aromatic hydrocarbons (PAHs) in smoked fish species from markets in Southern Nigeria. Toxicology Reports 4 (2017) 55-61.

[20] AFSSA (2003). AFSSA opinion on a request for an opinion on the risk assessment of benzo [a] pyrene $\mathrm{B}$ [a] $\mathrm{P}$ and other polycyclic aromatic hydrocarbons (PAHs), present in various commodities or in certain vegetable oils, as well as $\mathrm{PAH}$ concentration levels in commodities beyond which health problems may arise. French Food Safety Agency. Referral no. 2000-SA-0005.

[21] Vincent, V., Thierry, S., Fabrice, M., Bruno, L., and Carole, P. (2007). Determination of PAH profiles by GC-MS/MS in salmon processed by four cold-smoking techniques. J. Food Additives and Contaminants, July 2007, 24(7): 744-757.
[22] Perugini, M., Visciano, P., Giammarino, A., Manera, M., Di Nardo, W. and Amorena, M. (2007). Polycyclic aromatic hydrocarbons in marine organisms from the Adriatic Sea, Italy. Chemosphere, 66, 1904e1910.

[23] EFSA (2002) European Food Safety Authority. Scientific Committee on Food. Opinion on the risks to human health of polycyclic aromatic hydrocarbons in food, Italy.

[24] Maga, J. A., (1988), Smoke in Food Processing (Boca Raton, FL: CRC Press Inc).

[25] Bartle, K. D., 1991, Analysis and occurrence of PAHs in food. In: C. S. Creaser and R. Purchase (Eds.) Food Contaminants: Sources and Surveillance (Cambridge: Royal Society of Chemistry), pp. 41-60.

[26] Nakamura, T., Kawamoto, H. and Saka, S, (2008). Pyrolysis behavior of Japanese cedar wood lignin studied with various model dimers. J. of Analytical and Applied Pyrolysis, 81, 173-182.

[27] Essumang, D. K., Dodoo, D. K. and Adjei, J. K., 2013, Effect of smoke generation sources and smoke curing duration on the levels of polycyclic aromatic hydrocarbon (PAH) in different suites of fish. Food and Chemical Toxicology, 58, 86-94.

[28] Chukwujindu M. A., Francisca, I. B., Iwekumo, A., Eferhire, A., and Grace, O. B. I., 2016. Concentrations and risks of polycyclic aromatic hydrocarbons in smoke-cured fish products in Nigeria. International J. of Environmental Studies, 2016.

[29] Seyedeh, L. M. N., Wan, R. I., and Mohamad, P. Z. (2013). Residual Concentration of PAHs in Seafood from Hormozgan Province, Iran: Human Health Risk Assessment for Urban Population. International J. of Environmental Science and Development, Vol. 4, No. 4, August 2013. 